\title{
GRID-MODEL OF NATURAL AGRICULTURAL ZONING
}

\author{
Roman SHULGAN ${ }^{1}$, Olena KIBUKEVICH ${ }^{2}$, Oleksandr YANCHUK ${ }^{3}$, Kateryna NIKOLAICHUK ${ }^{4}$ \\ 1, 2, ${ }^{4}$ Department of Land Management, Cadastre, Land Monitoring and Geoinformatics, \\ Educational and Scientific Institute Agroecology and Land Management, \\ National University of Water and Environmental Engineering, Soborna str. 11, 33028 Rivne, Ukraine \\ ${ }^{3}$ Department of Geodesy and Cartography, Educational and Scientific Institute Agroecology and Land \\ Management, National University of Water and Environmental Engineering, Soborna str. 11, \\ 33028 Rivne, Ukraine \\ E-mails: ${ }^{1}$ romario20073@mail.ru (corresponding author); ${ }^{2}$ lenadey@ukr.net;

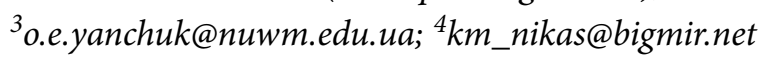

Received 6 January 2017; accepted 13 February 2017

\begin{abstract}
We have developed IDEF0 model of automated natural agricultural zoning technology based on the research of implementation of natural agricultural zoning, land management automation works with efficient application of new technologies and system approach. The hierarchical model has been developed, determining the weight of the main indicators. To construct GRID-model zoning elementary unit was determined. On the basis of the weights of indicators and obtained values of indicators, weighting coefficients of natural agricultural zoning are calculated and cells of GRID-model are combined according to their weight coefficients in natural agricultural districts by the method of "natural groups". As a result, we have a new border between Rivne and Ploska-Buderaz natural agricultural districts of Rivne region. To test the need to clarify the limits of natural agricultural districts, we fulfilled normative monetary evaluation of the land, which is located on the border of two natural agricultural districts. As a result of GRID-model use, the normative monetary valuation increased almost 2 -fold, resulting from a more detailed consideration of natural conditions of the area. The developed model makes it possible to automate the process of natural agricultural zoning and periodically make adjustments to the limits of districts depending on the change of the lands state and their indicators.
\end{abstract}

Keywords: automation, map of natural agricultural zoning, IDEF0 model, normative monetary evaluation, grid-model.

\section{Introduction}

Natural agricultural zoning is the basis for interrelation between natural environment and agricultural production. Now it needs to be clarified and informationally saturated due to the changes that have occurred in Land Fund of Ukraine along the period of land reform. Within each natural agricultural district, indicators of soil evaluation, land valuation, and, as a primary measure, determining the area of degraded soils and their distribution in the structure of agricultural lands have to be clarified (Kornilov et al. 2010). Their geographical location needs to be clarified as well because according to them carried normative monetary evaluation of agricultural lands.

According to the Land Code of Ukraine naturalagricultural zoning of land is the division of the area on the basis of natural conditions and agrobiological requirements of crops. It is also an information base of the state land cadastre and the basis for the development of land use.

The need for natural and agricultural zoning of lands is motivated by great diversity of natural conditions of Ukraine, causing a mandatory scientifically based differentiation of agricultural land use and protection.

Natural and agricultural zoning is based on a system built of hierarchical inter-subordinate taxonomic units - from natural and agricultural zone (the largest) to natural and agricultural district (the smallest). Ukraine includes such natural agricultural zones: Polissya, Forest-steppe and Steppe ones. 
Natural limits of agricultural areas in Ukraine have been formed before by taking into account the administrative-territorial division, namely the village councils, the smallest units.

The paper proposes to review the current approach to natural and agricultural zoning with the link to environmental conditions but not to the administrative-territorial boundaries. It is the application of GIS technologies that allows to take into account the distribution of natural conditions around the area.

\section{Analysis of research}

The problems of zoning, automation and efficient implementation of this work were explored by D. Martin, B. Danilishin, D. Dobryak, A. Hryanyk, A. Liashchenko, V. Mikhalevich, L. Nowakowski, A. Sokhnych, N. Tishchenko, A. Tretiak and other scientists.

As for the works on zoning of land resources as a part of land management in settlements, i.e. the formation of assessment districts and economic planning zones, the problems of zoning automation was tackled by S. Mogylniy, V. Shipulin, M. Krivobokov (Mohylnyi et al. 2004). They developed an automated method of combining estimated districts in economic planning zones. However, the actual values of indicators, were not applied in their works and therefore, to achieve high accuracy and reliability of zoning was not possible.

The automated zoning procedure (AZP) proposed by Openshaw is reviewed, and a population stress statistic proposed which may be used in an AZP algorithm in order to maximise the match between two zonal geographies. An implementation of this approach is described by D. Martin, and illustrated by reference to UK Census data (Martin 2001).

The clustering method using fuzzy set theory was developed in (Kryvobokov 2005), on the basis of which algorithmic GIS of automatical Territorial Units combining was created and zoning of cities of different sizes and values was made.

The automation of natural agricultural zoning has not been considered yet. The natural agricultural zoning is performed according to the Methodological Recommendations (UAinfo 2016), developed by D. Dobryak, O. Kanash, S. Osipchuk, A. Martin, K. Radchenko, S. Chernoshtan and approved by the State Committee of Ukraine for Land Resources.

\section{Research methods}

We have developed IDEF0 model of automated natural agricultural zoning technology based on the research of implementation of natural agricultural zoning, land management automation works with efficient application of new technologies and system approach (Bachyshyn et al. 2010, 2011; Kornilov et al. 2010) (Fig. 1).

The implementation of the model at the first stage (A1) involves determining the list of factors and corresponding indicators by which natural agricultural zoning takes place and their values for the area under

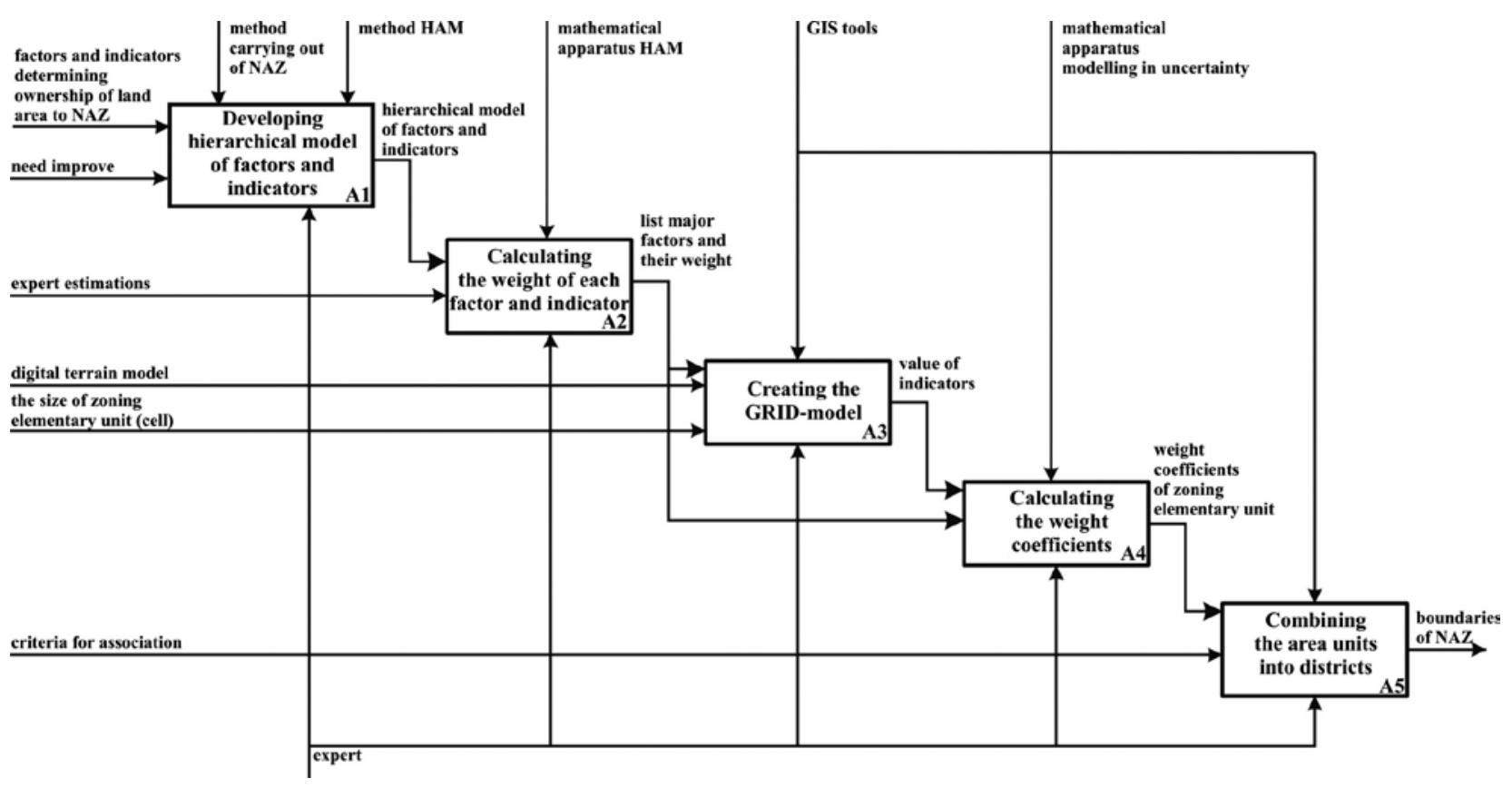

Fig. 1. IDEF0 model of automated natural agricultural zoning technology 
research. To analyze and evaluate the factors and indicators, we used the hierarchy analysis method (HAM), which makes it possible to specify more precisely the importance of criteria (Saaty 1993). To solve this prob$\mathrm{lem}$, the factors and indicators are considered as a system of criteria for affiliation of zoning elementary unit. The hierarchical model has been developed on the first level of which there is a facility, that is, the part of the territory which must be attributed to one or another natural agricultural district. The second level is represented by the most typical attributes. In the third level, there are indicators that reflect the natural and economic state of the area (Kornilov et al. 2010).

As a result of the application of mathematical tools of the hierarchy analysis method, weight factors and indicators (A2) in the zones of Polyssya and Forest Steppe of Rivne region were determined. The main ones that have weigh value more than 0.05 are summarized in Table 1. The sum of the values of the weights are normalized to the value of one.

To construct GRID-model (A3) with special GIS modules zoning elementary unit was determined. According to this approach, the particular area is divided by regular grid of $\mathrm{n}$ cells of a given size that is selected depending on the area peculiarity based on the factors that influence the zoning, i.e. depending on topography, differences in soils, river network, etc. This division is substantiated by the necessity to eliminate the above mentioned disadvantages of the current methods of natural agricultural zoning and the choice of zoning units smaller than the current unit - the territory of the village council.

Therefore, the selected area is divided into cells the size of $1000 \times 1000 \mathrm{~m}$, that is, each having to area of 100 hectares, that is roughly typical to the average area of agricultural land used by one farm in Ukraine (Derzhavnyi komitet statystyky 2010). In the Polyssya the optimal land area of agricultural enterprise is 500 1000 hectares, and in the Forest Steppe - 1000-1500 hectares (Budziak, V., Budziak, O. 2011). Therefore, each agricultural enterprise will be divided into 5-15 cells, which is sufficient to accurately consider the conditions of the area.
For the Polyssya and Forest Steppe zones, we determined the indicators listed in Table 1, although this list may vary depending on the location of natural agricultural zones. To determine the natural fertility, the mapping layer of agro-industrial groups of soils and their bonity grades are required that will be used as an indicator of fertility. To determine the steepness of slopes and altitude, we need a digital elevation model, as well as a digital models of rainfalls, hydrography and the depth of the water table. Thus, the values of indicators for each cell of GRID-model are determined automatically by means of GIS (Mapinfo professional 2016; Mapexpert 2016).

In our case, we selected the southern part of Zdolbuniv, part of Dubno and Ostrog administrative districts of Rivne region, because, it is here that the borders of Polyssya and Forest Steppe zones go. The set of the most important indicators were determined (Table 1): evaluation by natural fertility (bonity grade of a particular agro-industrial group of soils), slope steepness (degrees), altitude (meters), the amount of annual precipitation ( $\mathrm{mm} /$ year), the depth of the water table (meters), the density of the river network and the area water logging (points). For the latter value, because of the lack of quantitative characteristics, the following assessment scale was developed: 5 points in the selected area there are no water bodies, meliorative canals or wetlands, 4 points - there is a river or meliorative canals, 3 points - there are two rivers or partial water logging, 2 points - there is a river and partial or significant water logging, 1 point - the area is completely covered by a water body. We analyzed territorial change of the values of these indicators and established that while transiting from the Polyssya zone to the Forest Steppe zone soil values grow for the criterion of land fertility, that's soil bonity grade, steepness of slopes, altitude, the sum of active temperatures, the depth of the water table. Therefore, when calculating the weight values of the indicators were actually used the values of indicators themselves in each cell. And for such indicators as the amount of annual rainfall, river network density and waterlogged area, they, however, reduce. To save the growth patterns of the

Table 1. Weights of factors and indicators of natural agricultural zoning for the areas of Polyssya and Forest Steppe

\begin{tabular}{|c|c|c|c|c|c|c|}
\hline Factor & Soils & \multicolumn{2}{|c|}{ Terrain } & Climatic conditions & \multicolumn{2}{c|}{ Hydrological conditions } \\
\hline Indicator & fertility & slope steepness & altitude & $\begin{array}{c}\text { amount of annual } \\
\text { precipitation }\end{array}$ & $\begin{array}{c}\text { groundwater } \\
\text { depth }\end{array}$ & $\begin{array}{c}\text { river network } \\
\text { density }\end{array}$ \\
\hline $\begin{array}{c}\text { Weight index, } \\
\text { normalized to 1 }\end{array}$ & 0.081 & 0.208 & 0.208 & 0.174 & 0.207 & 0.122 \\
\hline
\end{tabular}


indicators from the zone of Polyssya to Forest Steppe, we used the numbers the inverse to their values.

After determining the weight of the main $\mathrm{m}$ indicators according to which the division into natural agricultural districts $\left(u_{1}, u_{2}, \ldots, u_{m}\right)$ is carried out, it is necessary to solve the problem of bringing the values of these indicators to a single scale. To do it, mathematical modeling of natural agricultural division of territories under uncertainty conditions was performed (Bachyshyn et al. 2011).

If the weighting coefficients are taken as integral values of weights the cells for all indicators then the present weight coefficient determines the relative degree of belonging the cell to a particular natural agricultural district. So, at the output we get a GRID-model, each cell of which contains the value of the weight coefficient (A4).

To combine the cells of GRID-model in natural agricultural districts (A5), that is to obtain the borders of units, one can either apply an algorithm based on the fuzzy set theory suggested by M. Krivobokov (Mohylnyi et al. 2004), or use GIS, namely, the division of the obtained values to ranges using "natural groups" method. The specified method allows creating ranges in accordance with the algorithm that uses the mean value within each range and divides the data so that the mean value of each range is the closest to each value in this range. This provides the best representation of the range mean values, and the fact that the within the range are closest to each other (Mapinfo 2016).

\section{The results of the research}

On the basis of the weights of indicators and obtained values of indicators, weighting coefficients of natural agricultural zoning are calculated and cells of GRID-model are combined according to their weight coefficients in natural agricultural districts by the method of "natural groups". As a result, we have a new border between Ploska-Buderaz and Rivne natural agricultural districts of Rivne region (Fig. 2).

As you can see, the current border between natural agricultural districts is somewhat different from the obtained one. The maximum deviation is around $6 \mathrm{~km}$. This is because during the previous natural agricultural zoning of the area, the boundaries between taxonomic units were attached to the administrative borders or the agricultural enterprises borders, despite of the fact that the natural conditions in a separate village council differ substantially.

The developed model makes it possible to automate the process of natural agricultural zoning and

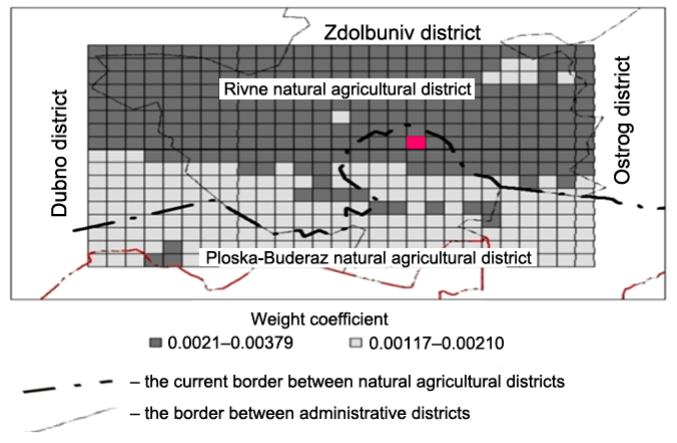

Fig. 2. Maps of natural agricultural zoning of Zdolbuniv district of Rivne region

periodically make adjustments to the limits of natural agricultural districts depending on the change of the lands state and their indicators. To do so it, will be only enough to make changes to the source data. Similarly, it is possible to unite natural agricultural districts in larger areas, provinces and zones. The model makes it possible to more accurately determine the real borders of natural agricultural districts in contrast to the current methods determining the districts according to the limits of village councils. Nowadays, with formation of agricultural land market in Ukraine, it is a rather essential aspect of research, because each natural agricultural district sets certain parameters taken into account in the assessment of land, especially agricultural ones. As a result, there may be cases of overestimated, or, conversely, underestimated market value of lands.

To test the need to clarify the limits of natural agricultural districts, we fulfilled normative monetary evaluation of the land plot highlighted in red in Figure 2, which is located on the border of two natural agricultural districts. According to the current division, the land plot refers to Ploska-Buderaz natural agricultural district of Polyssya zone and in accordance with the developed GRID-model it belongs to Rivne natural agricultural district of Forest Steppe zone. In the calculations we applied the input data to one area, and then to the other, and then compared the results (Table 2).

As a result of GRID-model use, the normative monetary valuation of the considered land plot increased almost 2 -fold, resulting from a more detailed consideration of natural conditions of the area.

According to the legislation of Ukraine (Podatkovyi kodeks Ukrainy 2016), the rate of tax on agricultural lands (arable lands) is set as a percentage of their normative monetary value amounting to 0.1 . Consequently, the land tax depends on the location of the land plot included in the natural agricultural district. In the examined case, due to the improved approach, the land tax will almost double. 
Table 2. Calculation of normative monetary evaluation of the land plot

\begin{tabular}{|c|c|c|c|c|c|c|}
\hline \multirow{3}{*}{$\begin{array}{l}\text { № } \\
1\end{array}$} & \multirow{3}{*}{$\begin{array}{l}\text { Indicator } \\
\text { index } \\
\text { П, ha }\end{array}$} & \multirow{2}{*}{ Indicator } & \multicolumn{4}{|c|}{ Value } \\
\hline & & & \multicolumn{2}{|c|}{ Forest Steppe } & \multicolumn{2}{|c|}{ Polyssya } \\
\hline & & Area of land & 1.47663 & 0.52337 & 1.47663 & 0.52337 \\
\hline 2 & & Name of land & cropland & cropland & cropland & cropland \\
\hline 3 & & Code of agroindustrial group of soils & $45 \Gamma$ & $40 \Gamma$ & $45 \Gamma$ & $40 \Gamma$ \\
\hline 4 & $\mathrm{~B}_{\text {agr }}$ & $\begin{array}{l}\text { Bonity grade of agroindustrial group of } \\
\text { soils }\end{array}$ & 48 & 52 & 27 & 28 \\
\hline 5 & B & $\begin{array}{l}\text { Bonity grade of a hectare of the } \\
\text { respective land in a farm }\end{array}$ & \multicolumn{2}{|c|}{22} & \multicolumn{2}{|c|}{22} \\
\hline 6 & M & $\begin{array}{l}\text { Normative monetary evaluation of a } \\
\text { hectare of the respective land in a farm }\end{array}$ & \multicolumn{2}{|c|}{26989.00} & \multicolumn{2}{|c|}{26989.00} \\
\hline 7 & $\mathrm{M}_{\mathrm{agr}}$ & $\begin{array}{l}\text { Monetary evaluation of agroindustrial } \\
\text { group of soils }\end{array}$ & 58885.09 & 63792.18 & 33122.86 & 34349.64 \\
\hline \multirow[t]{3}{*}{9} & $\mathrm{M}_{\mathrm{lp}}$ & $\begin{array}{l}\text { Summary normative monetary } \\
\text { evaluation of a separate land plot } \\
\Gamma_{\text {зд }}=\Gamma_{\text {aгp }} \times \Pi\end{array}$ & 86951.49 & 33386.91 & 48910.21 & 17977.57 \\
\hline & & Total & \multicolumn{2}{|c|}{120338.40} & \multicolumn{2}{|c|}{66887.78} \\
\hline & & Land tax & \multicolumn{2}{|c|}{120.34} & \multicolumn{2}{|c|}{66.89} \\
\hline
\end{tabular}

\section{Conclusions}

These results suggest that due to the improved approach using the latest GIS technology it is possible to more accurately take into account the natural environment of the areas. As can be seen from the results, it will significantly influence the monetary value of land and taxation. So, there is an urgent need in verification and further research of the territories on the borders of natural agricultural areas, in clarifying the limits of natural agricultural districts. Present-day technologies allow to automate this process using all the necessary input data. For full automation and providing updates, digital maps should be taken as a basis for zoning.

\section{References}

Bachyshyn, B.; Kornilov, L.; Kibukevich O.; Shulgan, R. 2010. Algorithm avtomatizacii pryrodno-silskogospodarskogo rayonuvannya, Visnyk NUVGP (3): 194-200 (in Ukrainian).

Bachyshyn, B.; Kornilov, L.; Kibukevich O.; Shulgan, R. 2011. Utochnennia mezh pryrodno-silskohospodarskykh raioniv na osnovi teorii nechitkykh mnozhyn, Visnyk heodezii ta kartohrafii (3): 32-36 (in Ukrainian).

Budziak, V.; Budziak, O. 2011. Problemy konsolidatsii zemel silskohospodarskoho pryznachennia, Naukovyi zhurnal Ekonomist (5): 58-60 (in Ukrainian).

Derzhavnyi komitet statystyky. 2010. Silske hospodarstvo Ukrainy za 2009 rik. Statystychnyi zbirnyk. Derzhavnyi komitet statystyky, Kyiv, Ukraina (in Ukrainian).

Kornilov, L.; Kibukevych, O.; Shulhan, R. 2010. Okremi aspekty vdoskonalennia pryrodno-silskohospodarskoho raionuvannia, Suchasni dosiahnennia heodezychnoi nauky ta vyrobnytstva 1(19): 300-305 (in Ukrainian).

Kryvobokov, M. H. 2005. Formalizatsiia otsinochnoho zonuvannia miskykh zemel z zastosuvanniam HIS-modeli: avtoref. dys. kand. tekhn. nauk. Kyivskyi natsionalnyi un-t budivnytstva i arkhitektury. Kyiv, Ukraina (in Ukrainian).

Mapexpert. 2016. User Guide ArcGis [online], [cited 24 March 2016]. Available from Internet: http://mapexpert.com.ua/ index_ru.php?po_2=1

Mapinfo professional. 2016. Mapinfo professional: user guide (Full) [online], [cited 24 March 2016]. Available from Internet: http://cps.ru/downloads/MapInfoProfessionalUserGuide_Ch2_WhatsNEw_950.pdf

Martin, D. 2001. Developing the automated zoning procedure to reconcile incompatible zoning systems, in Proceedings of the $6^{\text {th }}$ International Conference on GeoComputation University of Queensland, 24-26 September 2001, Brisbane, Australia [online], [cited 22 March 2016]. Available from Internet: http://www.geocomputation.org/2001/papers/martin.pdf

Mohylnyi, S.; Shypulin, V.; Kryvobokov, M. 2004. Avtomatyzatsiia ob'iednannia otsinnykh raioniv u ekonomiko-planuvalni zony, Suchasni dosiahnennia heodezychnoi nauky $i$ vyrobnytstva 1(19): 300-332 (in Ukrainian).

Podatkovyi kodeks Ukrainy [online], 2016 [cited 28 March 2016]. Available from Internet: http://zakon4.rada.gov.ua/ laws/show/2755-17 (in Ukrainian).

Saaty, T. 1993. Pryniatye reshenyi. Metod analyza yerarkhyi. Per. $s$ anhl. Moskva, Rossyia (in Russian).

UAinfo. 2016. Metodychni rekomendatsii shchodo zdiisnennia pryrodno-silskohospodarskoho raionuvannia (zonuvannia) zemel Ukrainy [online], [cited 22 March 2016]. Available from Internet: http://ua-info.biz/legal/basekt/ua-smpnkr. htm (in Ukrainian). 
Roman SHULGAN. Completed a Master degree in land management and cadastre in 2006 at the National University of Water and Environmental Engineering (Ukraine) and followed this with a PhD study in land cadastre and monitoring in 2013. Research area is related to the influence of environmental factors on the value of agricultural land, improved methods and models of monetary estimation.

Olena KIBUKEVICH. Completed a Master degree in land management and cadastre in 2006 at the National University of Water and Environmental Engineering (Ukraine). Research area is related to the impact of various factors on the development of territories agricultural enterprises, agriculturall and use modelling.

Oleksandr YANCHUK. Completed a Master degree in land management and cadastre in 2006 at the National University of Water and Environmental Engineering (Ukraine) and a Master degree in geodesy, cartography and land management in 2008 at the National University Lviv Polytechnic (Ukraine). Followed this with a $\mathrm{PhD}$ study in geodesy, photogrammetry and cartography in 2011. Associate Professor at the Department of geodesy and cartography at the National University of Water and Environmental Engineering (Ukraine) from 2015. Research area is related to geodetic monitoring, modern surveying technology, GIS modeling.

Kateryna NIKOLAICHUK. Completed a Master degree in land management and cadastre in 2003 at the National University of Water and Environmental Engineering (Ukraine) and followed this with a PhD study in land cadastre and monitoring in 2011. Research on application and the order of determination of rent-formation factors local coefficients values in normative monetary estimation of settlement lands has been carried out. 